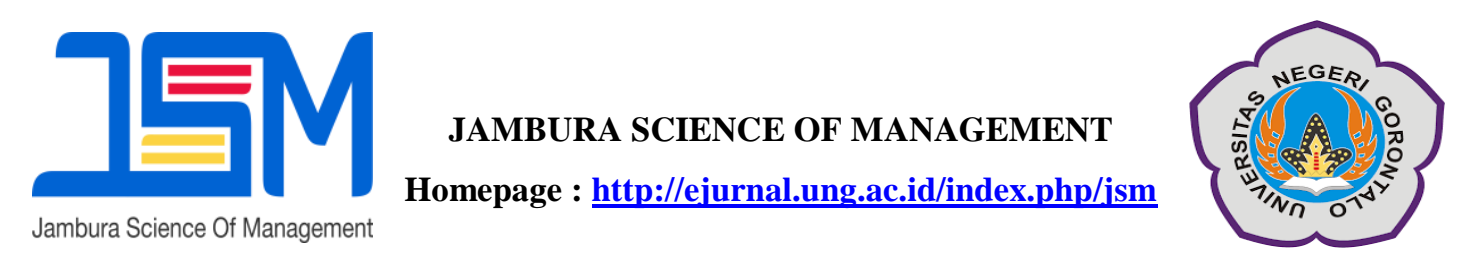

\title{
Comparison of Financial Performance Analysis of PT. Telekomunikasi Indonesia. Tbk and PT. Indosat. Tbk Period 2012-2016
}

\author{
Novarolina Dai \\ Department of Management, Faculty of Economics, Gorontalo State University \\ E-Mail:nova_dai@gmail.com
}

\begin{abstract}
:
This study aims to compare the financial performance of PT. Telekomunikasi Indonesia Tbk with PT. Indosat Tbk The 2012-2016 period uses the Financial Ratio method which includes liquidity ratios, leverage / solvency, activity, profitability. Based on the Statistical Test, it was obtained that all financial ratios of PT. Telekomunikasi Indonesia Tbk and PT. Indosat Tbk there is a significant difference. In descriptive analysis it can be concluded that the current ratio, debt to asset ratio, total asset turnover and return on assets of PT. Telekomunikasi Indonesia Tbk is better than PT. Indosat Tbk. So that from the two companies it can be concluded that PT. Telekomunikasi Indonesia Tbk has better financial performance compared to PT. Indosat Tbk during the period 2012-2016.
\end{abstract}

\section{Keywords: Financial Ratio, Financial Performance}

Since the enactment of Law No. 36/1999 concerning telecommunications and government regulations in 2002 which allowed foreign cellular operators to enter the Indonesian market, since then the Indonesian telecommunications industry entered the round of telecommunications liberalism. From the annual report of telecommunications companies in Indonesia, data is obtained that PT. Telekomunikasi Indonesia and PT. Indosat Tbk is two giant companies that dominate the cellular telecommunications industry in Indonesia. one important aspect that needs to be considered in carrying out the investment strategy in the stock market is by looking at the company's financial performance. To assess the financial performance of financial analysis requires a benchmark, namely financial ratios. the ratio used to assess the company's financial performance, namely liquidity ratio, leverage, activity and profitability. Liquidity ratio is used to measure a company's ability to meet short-term obligations. The leverage ratio is used to measure how many companies use funds from debt. The activity ratio measures the 
efficiency of a company in using its assets. Profitability ratios measure a company's ability to profit from the use of its capital.

Through financial ratio analysis, researchers can measure the extent of the financial situation of each company both telecommunications companies and Indosat companies so that they can know the comparison of financial conditions. And this is an interesting thing to examine how comparative analysis of financial performance between PT. Telekomunikasi Indonesia Tbk and PT. Indosat Tbk. The company's financial performance is one of the basic valuations regarding the company's financial condition which is based on an analysis of the company's financial ratios, by comparing the figures in the financial statements through the distribution of one number with other numbers in one period or several periods (Dudi, 2012 ; Fitria and Amanah, 2013; Candrasari, 2014).

\section{Current ratio}

CR of PT. Telekomunikasi Tbk from 2012-2016 had the lowest value of $106.22 \%$ in 2014. Then for the highest value of $135.29 \%$, which was in 2015 . The average and standard deviation of CR PT Telekomunikasi Indonesia Tbk, respectively amounting to $118.77 \%$ and $10.55 \%$. The value of the average variable CR PT Telekomunikasi Indonesia Tbk, which is greater than the standard deviation value indicates that the average value is a good representation in describing the CR PT Telekomunikasi Indonesia Tbk. Then for CR PT. Indosat Tbk from 2012-2016 had the lowest value of $40.63 \%$ in 2014 . Then the highest value was $75.43 \%$, which was in 2012. The average and standard deviation of CR PT. Indosat Tbk, which is $52.54 \%$ and $13.66 \%$ respectively. The value of the average variable CR PT. Indosat Tbk, which is greater than the standard deviation value indicates that the average value is a good representation in describing CR PT. Indosat Tbk.

\section{Debt to asset ratio}

DAR from PT. Telekomunikasi Tbk from 2012-2016 had the lowest value of $38.87 \%$ in 2014 . Then for the highest value of $43.78 \%$, namely in 2015. The average and standard deviation of DAR PT Telekomunikasi Indonesia Tbk, respectively amounting to $40.64 \%$ and $1.95 \%$. The value of the average DAR variable of PT Telekomunikasi Indonesia Tbk, which is greater than the standard deviation value indicates that the average value is a good representation in describing DAR PT Telekomunikasi Indonesia Tbk. Then for DAR PT. Indosat Tbk from 2012-2016 had the lowest value of $64.88 \%$ in 2012 . Then the highest value was $76.05 \%$, which was in 2015. The average and standard deviation of DAR PT. Indosat Tbk, which is $71.21 \%$ and $4.21 \%$ respectively. The value of the DAR variable of PT. Indosat Tbk which is greater than the standard deviation value indicates that the average value is a good representation in describing DAR PT. Indosat Tbk.

\section{Total asset turnover}

TATO of PT. Telekomunikasi Tbk from 2012-2016 had the lowest value of 0.61 in 2015 . Then for the highest value of 0.69 which is in 2012 . The average and standard deviation of TATO PT Telekomunikasi Indonesia 
Tbk, which is equal to 0,64 and 0.02 . The value of the average TATO variable of PT Telekomunikasi Indonesia Tbk which is greater than the standard deviation value indicates that the average value is a good representation in describing the TATO of PT Telekomunikasi Indonesia Tbk. Then for TATO PT. Indosat Tbk from 2012-2016 had the lowest value of 0.40 in 2012. Then for the highest value of 0.57 namely in 2016. The average and standard deviation of TATO PT. Indosat Tbk, which is respectively 0.46 and 0.06 . The value of the variable TATO PT. Indosat Tbk, which is greater than the standard deviation value indicates that the average value is a good representation in describing the TATO of PT. Indosat Tbk.

\section{Return on asset}

ROA of PT. Telekomunikasi Tbk from 2012-2016 had the lowest value of $14.03 \%$ in 2015 . Then for the highest value of $16.49 \%$, which was in 2012. The average and standard deviation of the ROA of PT Telekomunikasi Indonesia Tbk, respectively amounting to $15.56 \%$ and 0.98 . The average value of the ROA variable of PT Telekomunikasi Indonesia Tbk which is greater than the standard deviation value indicates that the average value is a good representation in describing the ROA of PT Telekomunikasi Indonesia Tbk. Then for the ROA of PT. Indosat Tbk from 2012-2016 had the lowest value of $-4.89 \%$ in 2012 . Then for the highest value of $2.51 \%$ namely in 2016 . The average and standard deviation of ROA of PT. Indosat Tbk, which is respectively $-1.41 \%$ and $3.06 \%$. The average variable ROA of PT. Indosat Tbk which is smaller than the standard deviation value indicates that the mean value is a poor representation in describing the ROA of PT. Indosat Tbk.

\section{METHOD}

In this study researcher conducted a comparative study approach with survey analysis. The time of research planned by researchers for 3 months, which includes the steps of research from preparation to the implementation of research. The research location is PT. Telekomunikasi Indonesia Tbk with PT. Indosat Tbk which is listed on the Indonesia Stock Exchange. The data analysis technique in this study used a statistical test, namely the two average difference test ( $t$ test) or in this study the $t$ test Independent test (Independent $\mathrm{t}$ test). The two difference test average will be used to determine the financial performance of PT. Telekomunikasi Tbk with PT. Indosat Tbk.

RESULTS AND DISCUSSION

Table 1: Comparison of Financial Performance of PT Telekomunikasi Indonesia Tbk and PT. Indosat Tbk

\begin{tabular}{|c|c|c|c|}
\hline Rasio & Yearn & $\begin{array}{c}\text { PT. Telekomunikasi } \\
\text { Indonesia Tbk }\end{array}$ & PT. Indosat Tbk \\
\hline \multirow{3}{*}{} & $\mathbf{2 0 1 2}$ & 116,04 & 75,43 \\
\cline { 2 - 4 } & $\mathbf{2 0 1 3}$ & 116,31 & 53,13 \\
\hline
\end{tabular}




\begin{tabular}{|c|c|c|c|}
\hline \multirow[t]{3}{*}{$\mathbf{C R}$} & 2014 & 106,22 & 40,63 \\
\hline & 2015 & 135,29 & 49,46 \\
\hline & 2016 & 119,97 & 42,30 \\
\hline \multicolumn{2}{|c|}{ Average } & 118,77 & 52,19 \\
\hline \multirow{5}{*}{ DAR } & 2012 & 39,86 & 64,88 \\
\hline & 2013 & 39,49 & 69,70 \\
\hline & 2014 & 38,87 & 73,34 \\
\hline & 2015 & 43,78 & 76,05 \\
\hline & 2016 & 41,24 & 72,11 \\
\hline \multicolumn{2}{|c|}{ Average } & 40,65 & 71,22 \\
\hline \multirow{5}{*}{ TATO } & 2012 & 0,69 & 0,40 \\
\hline & 2013 & 0,64 & 0,44 \\
\hline & 2014 & 0,63 & 0,45 \\
\hline & 2015 & 0,61 & 0,48 \\
\hline & 2016 & 0,64 & 0,57 \\
\hline \multicolumn{2}{|c|}{ Average } & 0,64 & 0,47 \\
\hline \multirow{5}{*}{ ROA } & 2012 & 16,49 & 0,88 \\
\hline & 2013 & 15,86 & $(4,89)$ \\
\hline & 2014 & 15,22 & $(3,49)$ \\
\hline & 2015 & 14,03 & $(2,1)$ \\
\hline & 2016 & 16,24 & 2,51 \\
\hline \multicolumn{2}{|c|}{ Average } & 15,57 & $(1,41)$ \\
\hline
\end{tabular}

(source: data processed, 2018)

All financial performance analyzed included four measured ratios, namely, CR, DAR, TATO and ROA, which showed that the financial performance of PT. Telekomunikasi Indonesia Tbk dominates overall compared to PT. Indosat Tbk. So it can be concluded that the financial performance of PT. Telekomunikasi Indonesia Tbk is far better than PT. Indosat Tbk.

To analyze financial performance there are several financial ratio analyzes used, namely: analysis of company liquidity (CR), financial structure analysis (DAR), company activity analysis (TATO), and analysis of company profitability (ROA). Based on the results of calculations and analysis performed, it can be seen in the graph of each of the following company performance:

\section{Current Ratio}

One of the liquidity ratios that can be used is the current ratio or current ratio. This ratio shows the extent to which current assets cover current liabilities. The greater the comparison of current assets with current debt, the higher the company's ability to cover its short-term liabilities. Judging from the results. Analysis of current ratio values from PT. Telkomunikasi Indonesia Tbk and PT. Indosat Tbk shows there are significant differences. The results of the analysis also show that PT. Indonesian Telecommunications, Tbk has a relatively better current ratio than PT. Indosat. current ratio value of PT. Indonesian Telecommunications, Tbk on average by 1.1876 (118.76\%). While for PT. Indosat, Tbk is only 0.5219 (52.19\%). This shows 
that PT. Telekomunikasi Indonesia Tbk has a much better liquidity condition compared to PT. Indosat, Tbk. The value of the current ratio is $118.77 \%$. This means that the current debt of PT. Telekomunikasi Indonesia Tbk amounting to $100 \%$ is borne or guaranteed by current assets of $118.77 \%$. If a comparison is made with industry standards of $200 \%$, then it can be seen that the average current ratio of PT. Telekomunikasi Indonesia Tbk and PT. Indosat Tbk is below the industry standard average.

\section{Debt to Asset Ratio}

The leverage ratio shows the company's ability to fulfill all its financial obligations if the company is liquidated. The results of the analysis of the leverage ratio measured by the DAR value from PT. Telekomunikasi Indonesia Tbk and PT. Indosat Tbk shows there are significant differences. This result is supported by a comparison of the DAR value between PT. Telekomunikasi Indonesia Tbk with PT. Indosat Tbk is quite large. DAR value of PT. Telekomunikasi IndonesiaTbk on average by $40.64 \%$. This value indicates that the amount of debt held by PT. Telkomunikasi Indonesia, Tbk is lower than the capital owned. While for PT. Indosat Tbk, the average DAR value is $71.22 \%$. This means that the total assets of the company PT. Indosat Tbk is more sourced from debt compared to its own capital. This condition will certainly have a negative impact on the performance of the company because with the increasing composition of interest, it will increase the company's interest expense which can reduce the profits earned. If the two are compared with the industry standard of $35 \%$, it can be seen that the DAR values of the two companies are above the industry standard average.

\section{Total Asset Turnover}

The results of the analysis of company activities are measured using the total asset turnover ratio of PT. Telkomunikasi Indonesia Tbk and PT. Indosat Tbk shows there are significant differences. This result is supported by a comparison of the value of TATO (total asset turnover) between PT. Indonesian Telecommunication Communication Tbk with PT. Indosat Tbk is quite large. TATO value from PT. Indonesian Telecommunication Communication Tbk on average is 0.65 times. This value is greater than the average value of TATO owned by PT. Indosat Tbk which is only 0.47 times. This TATO value shows the amount of rupiah that can be produced from every one rupiah of assets owned by the company. Thus the value of 0.65 can be interpreted that PT. Indonesian Telecommunication Communication Tbk is able to produce 0.65 rupiah from every one rupiah owned assets. In other words the company is able to utilize 0.65 value of assets owned to create sales / receipts. If these two values are compared with the average industry standard, which is equal to 2 times, then it appears that PT. Telekomunikasi Indonesia Tbk and PT. Indosat Tbk is still far below industry standards.

\section{Return On Asset}

The profitability ratio used in this study is the value of ROA. This ratio shows how much profit is obtained from each number of assets owned by the company. The higher the ROA value, the better the company's ability to generate profits. The results of the analysis of the ROA value of PT. Telkomunikasi 
Indonesia Tbk and PT. Indosat Tbk shows a significant difference. PT. Indonesian Telecommunications, Tbk always has a positive ROA value during 2012-2016 with an average of $15.57 \%$. While for PT. Indosat Tbk has a fluctuating ROA value. Even for three consecutive years namely 2013-2015, the ROA value that is owned is marked negative. This shows that for the past three years PT. Indosat, Tbk always suffer losses. On average, the value of ROA during the five years of observation also has a negative sign, which means that for the past five years the average company still suffered losses. If the two ROA values are compared with the industry standard of $30 \%$, it can be seen that the average ROA of PT. Telekomunikasi Indonesia and PT. Indosat Tbk is below the industry standard average.

\section{CONCLUSION}

Overall, the financial performance of PT. Telekomunikasi Indonesia Tbk, if measured by four ratios, namely the current ratio, debt asset ratio, total asset turnover, and return on assets dominates and is better than PT. Indosat Tbk. This result is a benchmark for PT. Indosat Tbk in order to continue to pay attention and make improvements related to the availability of current assets in overcoming the problem of liquidation of the company when it is unable to pay off its short-term debt. PT. Indosat Tbk must know about the sources of costs that will not have a major impact on the company's earnings and profits so that the company is able to increase its ability to earn profits or profits.

\section{REFERENCES}

Asyikin Jumirin dan Veronica Suryanti

Tanu. (2011). "Analisis

Perbandingan Kinerja Keuangan Antara Perusahaan Farmasi Milik Pemerintah (BUMN) Dengan Perusahaan Farmasi MIlik Swasta Yang Terdaftar Di Bursa Efek Indonesia." Jurnal Spread Vol.1 No. 1 April 2011.

Candrasari, Suciati Eka dan Suryono. 2014. Analisis Kinerja Keuangan Sebelum dan Sesudah Akuisisi Pada PT. Smartfren Telecom, Tbk. Jurnal Ilmu dan Riset Akuntansi. Vol. 3 No. 4

Rudianto, Dudi. 2012. Analisis Perbandingan Kinerja Keuangan PT. Telkom, Tbk Dengan PT. Indosat, $\quad$ Tbk Periode 2005-2010. Prosiding SNaPP2012: Sosial, Ekonomi, dan Humaniora.

Susilowati, Fitria dan Lailatul Amanah. (2013). “Analisis Kinerja Keuangan Sebelum Dan Sesudah Go Public." Jurnal Ilmu dan Riset Akuntansi. Vol. 2 No. 2 